\title{
REASONABLE ENTREPRENEURIAL RISK: BEHAVIOURAL CRITERIA FOR CORPORATE MANAGERS
}

\author{
SERGEY SOSNOVSKIKH, \\ De Montfort University (Leicester, United Kingdom) \\ OXANA CHERKASOVA, \\ Ural Federal University (Yekaterinburg, Russia)
}

https://doi.org/10.17589/2309-8678-2021-9-1-58-80

This paper discusses the essence of the entrepreneurial risk, ethical and legal standards, which must be adhered to by the head of a commercial organisation. In the Russian legislation, there is debate concerning the boundaries of the responsibilities of the corporate manager. Existing literature doesn't contain many studies about the norms on the responsibility of persons authorised to act on behalf of a legal entity because it is new for Russian civil legislation, which shows the novelty of this study. We identify problematic aspects that arise both in the doctrine and judicial practice regarding the determination of the criteria of good faith and reasonable behaviour of the head of the corporation. Our study examines the legal nature of entrepreneurial risk and how it affects the formation of managerial decisions. As a result, we propose a basic model of the criteria for the good behaviour of a corporate manager within a reasonable entrepreneurial risk.

Keywords: entrepreneurial risk; business risk; corporate governance; corporate conflict; good faith; reasonableness; corporate law; civil law; Russia.

Recommended citation: Sergey Sosnovskikh \& Oxana Cherkasova, Reasonable Entrepreneurial Risk: Behavioural Criteria for Corporate Managers, 9(1) Russian Law Journal 58-80 (2021). 


\section{Table of Contents}

Introduction

1. Theoretical Analysis and Literature Review

1.1. Fiduciary Duties of a Corporate Manager

1.2. Corporate Social Responsibility and the Corporate Governance

1.3. Reasonable Business Risk: Legal Perspective

1.4. Management View on Concepts of the Behaviour

of the Corporate Manager

2. Legal and Enforcement Aspects of the Fiduciary Duties of the Head of the Corporation Within Limits of Entrepreneurial Risk

2.1. Legal Regulation of Standards of Conduct for a Corporate Manager

2.2. Practical Aspects of Law Enforcement in Determining the Behavioural Criteria for the Head of Corporation: Judicial Discretion

3. Analysis

3.1. Case Discussion No. 1: Anglo-Saxon Judicial Practice

3.2. Case Discussion No. 2: Russian Judicial Practice

3.3. Case Discussion No. 3: Russian Judicial Practice

4. Discussion

Conclusion

\section{Introduction}

In the context of the development of a market economy in Russia, one of the priorities of the government is to ensure the equal rights of business entities, which largely depend on professional decisions of the senior management. 'The business strategy should be long-term and aim to follow its best interests of the company evaluating specific circumstances of the market. Hence, individual transactions of the governing body must be assessed in the context of the organisation's strategy. ${ }^{2}$ As part of the reform of Russian civil law, several changes have been made related to the expansion of the powers of the executive body. This has provided new opportunities in the management. However, also intractable corporate conflicts have begun to grow often resulting in lengthy litigation. Consequently, it has caused colossal property and personal losses both for managers and companies. ${ }^{3}$

This paper aims to determine the criteria for the behaviour of the head of the corporation within a reasonable entrepreneurial risk. We set the following research

Vladimir Orlov, Introduction to Business Law in Russia (2013).

2 Gerry Johnson et al., Exploring Strategy (2014).

3 Alexander Pavlov et al., The Description of Unfair Competition Under the Current Legislation of the Russian Federation, 11(21) Asian Soc. Sci. 15 (2015). 
objectives: 1) Investigate the scientific and practical approaches in determining the categories of good faith and reasonable entrepreneurial risk; 2) Analyse the legal and enforcement aspects of the behaviour of the corporate manager within a reasonable entrepreneurial risk and formulate the problem fields; 3) Provide recommendations on resolving identified problems; and, 4) Develop criteria that determine the good faith behaviour of the leader within a reasonable entrepreneurial risk that meets the requirements of both doctrine and legal practice.

In this work, we used a system of methods derived from both economic and legal sciences. We studied the behavioural standards of the corporate managers in terms of various theoretical, scientific and practical positions. The legal method of systemstructural analysis enabled to identify heterogeneous judgments regarding the criteria for determining the reasonable behaviour of a business leader in making managerial decisions and suggest possible ways to resolve existing contradictions. We used the laws and acts of Russian law and the relevant literature for our study.

This paper is structured as follows. A literature review, section 2, discusses the essence of corporate management in the Anglo-Saxon (with a specific focus on Company Law 2006) and Russian jurisdictions. It also covers the essence of corporate social responsibility (CSR) in Russia and the EU, provides the clarification of the reasonable business risk from the legal perspective, and debates on the concepts of the behaviour of the corporate manager from the management point of view. In section 3, we focus on legal and enforcement aspects of the fiduciary duties of the head of the corporation within limits of entrepreneurial risk. Within this section, we explain the legal regulation of standards of conduct for a corporate manager, the standards of good faith and reasonableness as elements of Russian corporate law, and practical aspects of law enforcement in determining the behavioural criteria for the head of the corporation. Section 4 provides a critical discussion of three cases from Anglo-Saxon and Russian judicial practices. In Section 5, we present and discuss the findings, proposing the behavioural model of the head of the corporation that defines the legal criteria for the good faith and reasonableness to the extent permitted by entrepreneurial risk. Finally, the paper concludes with a reflection on the implications of the findings for the future development of Russian law in corporate management.

\section{Theoretical Analysis and Literature Review}

\subsection{Fiduciary Duties of a Corporate Manager}

Attempts to establish general legal criteria for assessing the acceptability of managerial decisions that would satisfy both private and public interests have been frequently made both in Russia and abroad. Before Company Law 2006 came into force in the Anglo-Saxon jurisdiction, the issue of fiduciary duties of the head of the company was the subject of scientific discussions. According to the traditional approach, the responsibilities of directors to the company and its shareholders 
were essentially determined by case law. The director's position corresponds to the position of the fiduciary, i.e. person entrusted with the management of the property in the interests of another person. ${ }^{4}$ According to the right of equity, the actions of company management within the framework of a reasonable entrepreneurial risk are typically called as the standard of behaviour of directors. ${ }^{5}$ The English legal experts suggest that the managerial behavioural standards in the implementation of business decisions are inevitably associated with entrepreneurial risk. The arguments for and against the codification of duties of directors were examined by Law Commissions and consequently by the Company Law Review before 2006. Their considerations formed the basis for the draft of the Company Bill, which subsequently replaced the existing common law obligations with seven statutory obligations: 1) to act within powers, 2) to promote the success of the company (loyalty), 3) to exercise independent judgement, 4) to exercise reasonable care, skill and diligence, 5) to avoid conflicts of interest; 6) not to accept benefits from third parties, 7) to declare an interest in a proposed transaction or arrangement ${ }^{6}$. The change from common law to codified duties was estimated as crucial to ensuring more effective corporate governance; hence, better corporate responsibility. The Companies Act 2006 established a new balance between companies and society, and there is hope that through this new balance, companies and society will find a compromise.?

One of the main goals of the codification process in English corporate law was to increase the accessibility, coherence and comprehensibility to company directors specifically of small and medium enterprises. ${ }^{8}$ Fiduciary duties are considered as assessment standards of behaviour of the head of the organisation, since the head and the corporation are connected by the personally-trusting nature of the relationship. Ribstein strives to systematise the concept of fiduciary duty in relation to corporate governments. ${ }^{9}$ The scholar believes that fiduciary duty is a continuation of managerial discretion, which is delegated from the owners to the governing body, whereas fiduciary duties are based on a contractual relationship between owners and company management. Nosworthy notes that fiduciary relations between the owner and the manager play a key role in achieving good faith by the governing body. ${ }^{10}$ Langford claims that the fiduciary duty of directors is to act in good faith

4 David Collison at el., Financialization and Company Law: A Study of the UK Company Law Review, 25(1) Crit. Perspect. Account. 5 (2014).

5 Id.

6 Arden Dbe, Regulating the Conduct of Directors, 10(1) J. Corp. L. Stud. 1 (2010).

7 Id.

8 Parker Hood, Directors' Duties Under the Companies Act 2006: Clarity or Confusion?, 13(1) J. Corp. L. Stud. 1 (2013).

9 Larry E. Ribstein, Are Partners Fiduciaries?, 2005(1) U. III. L. Rev. 209 (2005).

10 Beth Nosworthy, A Director's Fiduciary Duty of Disclosure: The Case(s) Against, 39(4) U.N.S.W.L.J. 1389 (2016). 
in the interests of the company. ${ }^{11}$ In Australia, this provision is in doubt because the Supreme Court has narrowed its understanding of this fiduciary principle. In contrast, under UK law, the criteria are better clarified. ${ }^{12}$ A fiduciary duty directly puts shareholders at the centre of the company's interests. It assigns priority right to shareholders with respect to all other interested parties. According to Keay et al., this is an attempt to codify the obligation of the common law to act in good faith in the interests of the corporation, which remains extremely important for the interpretation and application of the modern requirement of good faith. ${ }^{13}$

Russian scholars expressed similar ideas in the field of corporate governance. Lutsenko states that it is crucial to determine the interests of the company in the internal documents. ${ }^{14}$ At the same time, the interests of the company (which are ensured by the protection of subjective law) are derived from the economic interests of owners. Since the interests of the organisation are not inextricably linked with the interests of the owners, but are predetermined by them, therefore, the satisfaction of the interests of the company ensures the satisfaction of the interests of its owners. According to Kozlova and Philipova, determination of the organisational goals helps senior management to focus its efforts on certain areas. ${ }^{15}$ Compliance with the goal and subject of the organisation's activity is one of the criteria for evaluating the effectiveness and legitimacy of the actions of its management. The integrity and reasonableness of the actions of the head of the organisation are determined based on the adoption of the necessary and sufficient measures to achieve the goals for which the legal entity was created. The actions of members of the bodies of a legal entity in contradiction with the goals of its activities may serve as the basis for their prosecution, following Article 53.1 of the Civil Code of the Russian Federation. ${ }^{16}$

Adequate reflection of the purpose and subject of activity of a legal entity in its constituent document is of great importance both for the legal entity itself and for

11 Rosemary T. Langford, The Duty of Directors to Act Bona Fide in the Interests of the Company: A Positive Fiduciary Duty? Australia and the UK Compared, 11(1) J. Corp. L. Stud. 215 (2011).

12 Id.

13 Andrew Keay et al., Business Judgment and Director Accountability: A Study of Case-Law over Time, 20(2) J. Corp. L. Stud. 1 (2019).

14 Луценко С.И. Роль фидуциарных принципов в совершенствовании корпоративного управления // Общество и экономика. 2016. № 3. C. 41-50 [Sergey I. Lutsenko, The Role of Fiduciary Principles in Enhancement of Corporate Governance, 3 Society and Economy 41 (2016)].

15 Козлова Н.В., Филиппова С.Ю. Гражданская правосубъектность юридического лица: комментарий новелл Гражданского кодекса РФ // Законодательство. 2014. № 9. C. 9-19 [Natalia V. Kozlova \& Sophia Yu. Philipova, Civil Personality of a Legal Entity: Commentary on the Short Stories of the Civil Code of the Russian Federation, 9 Legislation 9 (2014)].

16 Гражданский кодекс Российской Федерации (часть первая) от 30 ноября 1994 г. № 51-Ф3 [Civil Code of the Russian Federation (Part One) of 30 November 1994 No. 51] (Sep. 2, 2020), available at http://www.consultant.ru/document/cons_doc_LAW_5142/1937c3c06a7ba397ca3d0ea54a99ea5 $94 \mathrm{~b} 1 \mathrm{e} 6446$. 
its counterparties, founders (owners), and senior management. In the corporate culture of Russian companies, the goals with focus on profit are rarely detailed in the constituent documents. Instead, they are determined from its business plans, strategic concepts, internal documents, and established business practices. ${ }^{17}$ The concept of concretising the fiduciary duties of a corporate manager in the interests of the company is not only attractive to Russian scholars. Ho proposes borrowing the provisions of Section 172 of the UK Company Act 2006, which includes the concept of enlightened shareholder value, as well as a list of non-exhaustive factors (criteria) that directors must consider when promoting the success of a company. ${ }^{18}$

\subsection{Corporate Social Responsibility and the Corporate Governance}

One of the options for a reasonable combination of the profitability of business activity and public benefit is social entrepreneurship, which aims at mitigating or resolving social problems. In Russia, the businesses have only recently started to realise the importance of the social function. ${ }^{19}$ In developed countries, the role of commercial organisations in the public sector is no longer limited to job creation and paying taxes only. Businesses are expected to solve social issues and satisfy social needs, which traditionally belong to the competence of the government. ${ }^{20}$ Understanding the essence of the social function of entrepreneurship creates favourable conditions for harmonising the interests of the government and private sector, and also for redistributing the responsibility of solving social problems. For this, it is necessary to create such mentality and culture in Russian society that would help motivate businesses to take care of the image of their morally justified activities in the eyes of the population. ${ }^{21}$ Within the context of the CSR relevance, the formation of a moral and ethical model of the behaviour of the head of a business structure is important. Bereskin et al. suggest that the more a corporate manager takes into consideration socially significant goals, the less likely it makes mistakes as well as unprofessional and disadvantageous decisions for the corporation. ${ }^{22}$

17 Irina Krasnopolskaya, Corporate Foundations in Russia: Overview of the Sector in Handbook on Corporate Foundations: Corporate and Civil Society Perspectives 149 (Lonneke Roza et al. eds., 2020); Mikhail Kulapov et al., Corporate Culture of Organization: Typical and Russian Model, 15(1) Montenegrin J. Econ. 215 (2019).

18 John K.S. Ho, "Director's Duty to Promote the Success of the Company": Should Hong Kong Implement a Similar Provision?, 10(1) J. Corp. L. Stud. 17 (2010).

19 Andrei Kuznetsov \& Olga Kuznetsova, Business Legitimacy and the Margins of Corporate Social Responsibility in the Russian Context, 42(3) Int. Stud. Manag. Organ. 35 (2012).

20 Catherine Malecki, Corporate Social Responsibility: Perspectives for Sustainable Corporate Governance (2018).

21 Jo Crotty, Corporate Social Responsibility in the Russian Federation: A Contextualized Approach, 55(6) Bus. Soc. 825 (2014).

22 Frederick Bereskin et al., Whistle Blowing, Forced CEO Turnover, and Misconduct: The Role of Socially Minded Employees and Directors, 66(1) Manag. Sci. 24 (2019). 
In the EU, the official discussion of about CSR started in the 2000s. Initially, its idea was about the scope of the responsibility of companies towards their environment. Over time, this became a process in which business representatives began to play a significant role, and their goal was to facilitate learning among business organisations rather than determine the components of the regulatory framework for CSR. De Schutter questions whether there will be enough market forces to encourage companies to act responsibly beyond their obligation to comply with their legal requirements. ${ }^{23}$ The author suggests that this case is based on certain assumptions regarding markets and the business environment, which cannot merely be assumed, but which should be positively created by the regulatory framework for CSR. De Schutter also proposes that the erroneous opinion takes place in the EU that the creation of a regulatory framework for CSR threatens the competitiveness of European firms. ${ }^{24}$ Moreover, there is a contradictory opinion that the reliance on market mechanisms will be sufficient to ensure that corporations seek to minimise the negative social and environmental consequences of their activities, even when they are not required to do so by law. Horn highlights the fundamentally political nature of corporate governance regulation. ${ }^{25}$ The author claims that the transformation of corporate governance regulation is part of a broader political project for economic restructuring and market formation in the EU. Company Law has become more focused on the rights of shareholders. In contrast, the rights of workers have been allotted in the field of social policy and labour law. Horn also traces the transition from a legislative program aimed at harmonising Company Law to a regulatory approach based on minimum requirements and mutual recognition, which is increasingly focused on adapting corporate governance to the requirements of liberalised capital markets. ${ }^{26}$

\subsection{Reasonable Business Risk: Legal Perspective}

In the identification of the criteria for good faith and prudent management, one of the limits is an entrepreneurial risk. The doctrine of Russian Civil Law provides a wide variety of interpretations of entrepreneurial risk. According to Dolinskaya, risk is characterised by independence and conscious assumption of any result of activity, as well as potential mismatch of the expected outcome and the result. ${ }^{27}$ Lukyanenko defines a reasonable entrepreneurial risk as a conscious choice by an entrepreneurial subject of one of the alternative behaviours in a risky situation,

23 Olivier De Schutter, Corporate Social Responsibility European Style, 14(2) Eur. L.J. 203 (2008).

24 Id.

25 Laura Horn, Corporate Governance in Crisis? The Politics of EU Corporate Governance Regulation, 18(1) Eur. L.J. 83 (2012).

26 Id.

27 Долинская В.В. Акционерное право: основные положения и тенденции [Vladimira V. Dolinskaya, Stock Law: Key Points and Trends] (2006). 


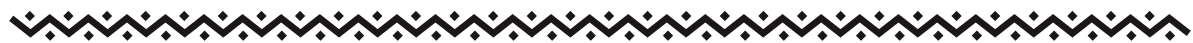

characterised by the uncertainty of the predicted result and the subjectivity of its assessment. ${ }^{28}$ If there is a risk, the subject has real chances of making a profit. At the same time, there is a likelihood of adverse property or other consequences occurring, if the intended action (managerial decision) is not carried out, as well as if miscalculations or errors are made in making managerial decisions. However, Vlasova emphasises the unfoundedness of the appeal to the category of entrepreneurial risk, and the definition of the scope of its application, in particular, in civil matters. ${ }^{29}$ The author questions the use of this concept in the context of disputes related to the activities of the head of a business company. As a result, a remarkable dilemma arises in which the assessment of the behaviour of the head of the company, who is not an entrepreneur in itself, is oriented to the rules of a market economy. At the same time, the director is personally liable for the losses caused to the corporation by unlawful actions with his personal property.

Undertaking knowledgeable management decisions can occur in a situation that does not involve any unique behaviour model. The standard entrepreneurial risk gives management bodies the freedom to conduct business and exempts from clarity within the boundaries established by entrepreneurial activity. ${ }^{30}$ Some risks cannot be foreseen initially when making a decision, but there are obvious risks that cannot be ignored when concluding a transaction. References to the risky nature of banking sector as a type of entrepreneurial activity when applying subsidiary liability for the debts of a credit institution cannot be taken into account in cases where the debtor did not initially constitute a financially stable structure, or the individual did not have adequate solvency, or there was no adequate enforcement of their obligations. These facts existed at the time of the conclusion of the transaction and, therefore, could not have signs of probability and chance of occurrence. Thus, the individual responsible for making the decision, in any case, should investigate those circumstances that were objectively known at the time of its adoption. ${ }^{31}$ In order for the risk to fall within limits established by the fiduciary duties of the manager, it must be reasonable and justified. A similar principle of exemption from liability for "commercial failure" meets the requirements of entrepreneurial turnover. ${ }^{32}$

Лукьяненко М.Ф. Оценочные понятия гражданского права: разумность, добросовестность, существенность [Marina F. Lukyanenko, Valuation Concepts of Civil Law: Reasonableness, Integrity, Materiality] 433 (2010).

29 Власова А.С. Риск, ответственность и вина в предпринимательских отношениях // Безопасность бизнеса. 2012. № 1. C. 36-40 [Anna S. Vlasova, Risk, Responsibility, and Guilt in Entrepreneurial Relations, 1 Business Security 36 (2012)].

30 Lowell W. Busenitz, Entrepreneurial Risk and Strategic Decision Making: It's a Matter of Perspective, 35(3) J. Appl. Behav. 325 (1999).

31 Hennie van Greuning \& Sonja Brajovic Bratanovic, Analyzing Banking Risk: A Framework for Assessing Corporate Governance and Risk Management ( $3^{\text {rd }}$ ed. 2009).

32 Rutheford B Campbell, Jr. \& Christopher W. Frost, Managers' Fiduciary Duties in Financially Distressed Corporations: Chaos in Delaware (and Elsewhere), 32(3) J. Corp. L. 491 (2007). 


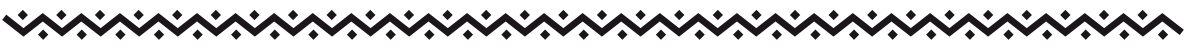

The aspect of how the concepts of guilt and risk are interrelated deserves close attention because it is ambiguously considered in the doctrine of Russian civil law. The policymaker uses the criterion of prudence and care to determine guilt. ${ }^{33}$ It establishes different directions in which an individual should undertake measures (actions) and by means of which an individual's mental attitude (guilt) is established. Prudence characterises mainly the attitude to the external world such as contractors, government, customers, partners, etc. - to those for whom the manager's control is insignificant and indirect. Caring is a manifestation of the entrepreneur's attitude to the internal world, such as management structure, personnel, and business processes that the corporate manager can influence directly and the most. Hence, if the corporate manager intentionally analyses the circumstances of the transaction carelessly, does not take into account the objectively existing risk, does not evaluate it and undertake the measures available to minimise the possible negative consequences, then its actions should be considered unreasonable and unscrupulous. ${ }^{34}$ Such actions are the basis for attracting the head of the business structure to property liability for losses. Therefore, we suggest that the signs of the guilt of the subject of responsibility are the right direction for determining the criteria of good faith and reasonableness in making managerial decisions.

\subsection{Management View on Concepts of the Behaviour of the Corporate Manager}

Considering the behavioural standards of a company manager is somewhat more comprehensive, going beyond the framework of legal science, special attention should be paid to some theoretical concepts of management. According to Mintzberg, the role of the leader is determined by a set of behavioural rules that correspond to a specific organisation or competitive position. ${ }^{35}$ Corporate managers develop organisational strategies and act as the main communicating channel between their organisation and the environment, as well as are responsible for the outcomes of the business activity. Management models of corporate behaviour define the categories of reasonableness and justice within the framework of the legal field. The following criteria for evaluating the behaviour of a leader can be taken as a basis. The leader acts "reasonably" when it possesses the following qualities. Filatotchev and Nakajima suggest the importance of self-management and high culture of personal work, the ability to distribute strength, the objectivity in assessing the events combined with the desire to know the opinions of others. ${ }^{36}$ Hodges emphasises the sociability,

Поваров Ю.С. Акционерное право России [Yuri S. Povarov, Joint Stock Law of Russia] 705 (2017).

${ }^{34}$ Id.

35 Henry Mintzberg, Strategy-Making in Three Modes, 16(2) Calif. Manag. Rev. 44 (1973).

36 Igor Filatotchev \& Chizu Nakajima, Corporate Governance, Responsible Managerial Behavior, and Corporate Social Responsibility: Organizational Efficiency Versus Organizational Legitimacy?, 28(3) Acad. Manag. Perspect. 289 (2014). 
understand as the ability to establish and maintain contacts and connections, and clearly recognise and formulate personal goals connected with personal life and work. ${ }^{37}$ Understanding goals fully allows the corporate manager to judge how important it is for him/her what he/she does, how work fits into his/her life's strategy. This forms personal motivation, promotes consistency and solidity in decisionmaking. Van Greuning and Brajovic-Bratanovic propose managerial competence as a basic knowledge of contemporary management and the ability to put it into practice. ${ }^{38}$ Moreover, specialised competence is needed as knowledge of special issues determined by the profile and specifics of the organisation activity, as well as erudition in areas of marketing, economics, labour and economic legislation.

The "good faith" implies the following qualities in the leader. According to Marnet, there is psychological intuition, which is the ability to understand the mental properties and state of a person; and, psychological contact, which is the ability to find the right form of communication. ${ }^{39}$ Tricker suggests sociability, which is the ability to establish and maintain contacts and communications; the desire to take responsibility; flexibility, which implies the ability to get re-oriented from ineffective strategies and tactics quickly; and, the ability to maintain self-control in unforeseen situations. ${ }^{40}$ Therefore, both management and legal sciences see rationality (reasonableness) as a combination of objective skills and abilities, and good faith as a consolidation of the subjective qualities of a leader. We suggest that an interdisciplinary approach can contribute to a more in-depth disclosure of these concepts in legal practice. At the same time, the reasonableness of the actions of the executive body of the corporation predetermines its behaviour in good faith and, in general, acts as a fundamental criterion for good-faith behaviour.

A high degree of risk is present in the activity of making managerial decisions in those business entities for the property of which there are conflicting interests of many interest groups, i.e. stakeholders ${ }^{41}$. These are the interests of shareholders to receive dividends from invested funds; employees to receive stable and higher wages and other social benefits; the similar requests from the management; suppliers and contractors; and, the state authorities in collecting taxes, permissions, and other obligatory payments. ${ }^{42}$ Due to the limited resources of a private organisation, it is challenging to make a decision that fully satisfies the interests of all the groups. For any managerial decision, one can always be found whose property interest does not

37 Christopher Hodges, Law and Corporate Behaviour: Integrating Theories of Regulation, Enforcement, Compliance and Ethics (2015).

38 Van Greuning \& Brajovic Bratanovic 2009.

39 Oliver Marnet, Behavior and Rationality in Corporate Governance, 39(3) J. Econ. Issues 613 (2015).

40 Bob Tricker, Corporate Governance: Principles, Policies, and Practices (2015).

41 Sebastian Vaduva et al., Moral Leadership in Business: Towards a Business Culture of Integrity (2016).

42 Id. 


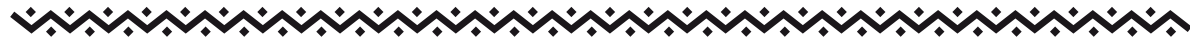

satisfy a managerial decision. The multiplicity of individuals and interests, the risky and competitive nature of entrepreneurial activity partly explain the wide variability of possible managerial decisions. It is challenging to develop impeccable formulas and algorithms for all occasions that establish how exactly the numerous factors affecting the decision-making process by the management bodies of commercial organisations should be taken into account. ${ }^{43}$ Therefore, it is necessary to have a clearly formulated system of legal regulations of the standards of behaviour of the head of the company, as well as the boundaries of its responsibilities. In this paper, we critically discuss the Russian legal framework in the field of corporate governance.

\section{Legal and Enforcement Aspects of the Fiduciary Duties of the Head of the Corporation Within Limits of Entrepreneurial Risk}

\subsection{Legal Regulation of Standards of Conduct for a Corporate Manager}

The standards of "good faith" and "reasonableness" as elements of Russian corporate law are defined in the Code of Corporate Conduct adopted at the level of the Central Bank of Russia at a meeting of the Federal Government. ${ }^{44}$ The development of the Russian Code of Corporate Conduct has become an essential milestone in the development of corporate relations in the Russian Federation. ${ }^{45}$ With the adoption of the Code, Russian joint-stock companies received basic guidelines for the implementation of advanced corporate governance standards, taking into account the specifics of Russian legislation and the established practice on the relationship between shareholders, members of the board of directors (supervisory board hereinafter referred to as the board of directors), executive bodies, employees and other interested parties involved in the economic activities of joint-stock companies. The Code offered shareholders and investors articulated approaches to what should be required of companies and contributed to increasing the activity of shareholders and investors. ${ }^{46}$ However, the provisions of this document are advisory.

The Code of Corporate Conduct introduced the criteria of integrity and reasonableness of action in the public interest. ${ }^{47}$ In addition to the absence of personal interest, it is envisaged to exercise the discretion and care that should be expected from a good leader; decision-making taking into account all available information

\footnotetext{
43 Hodges 2015.
}

44 Approved at a meeting of the Federal Government of the Russian Federation on 28 November 2001, and recommended for use by joint-stock companies by order of the Federal Commission of Securities Market of Russia of 4 April 2002 No. 421/r "On Recommendations for the Application of the Code of Corporate Conduct."

45 Krasnopolskaya 2020.

$46 \quad$ Id.

47 Scott A. Shostak, Russia Corporate, Financial, and Commercial Law (2018). 
and in the absence of a conflict of interest, taking into account the equal treatment of the company's shareholders within the framework of ordinary entrepreneurial risk (para. 2.6.1); ${ }^{48}$ the desire to achieve sustainable and successful development of society (para. 126). ${ }^{49}$ In response to the violation of the fiduciary duties by the head of the company, the owner may initiate a judicial procedure. Besides, the legal foundations of managerial activities of business managers are reflected in paragraph 3 of Articles 53 and 53.1 of the Civil Code of the Russian Federation, which were detailed in special laws: Article 71 of the Federal Law of 26 December 1995 No. 208 "On Joint-Stock Companies," Article 44 of the Federal Law of 8 February 1998 No. 14 "On Limited Liability Companies." Of particular importance is the special rule of Article 71 of the Federal Law "On JointStock Companies," which provided an additional criterion for the good faith conduct of the head - "ordinary business conditions." This rule gave the courts a big field for evaluating management decisions. However, excessive detailing is also undesirable, since the risky and independent nature of entrepreneurship dictates the necessities giving the governing bodies broad discretion in choosing ways to conduct their activities. Thus, the modern Russian policymaker refused to specify the conditions for making managerial decisions and used mainly evaluative concepts - conscientiousness, reasonableness, prudence, caring, and ordinary business conditions. ${ }^{52}$

\subsection{Practical Aspects of Law Enforcement in Determining the Behavioural Criteria for the Head of Corporation: Judicial Discretion}

Moral and ethical criteria which are adjusted by the reasonable entrepreneurial risk of managerial behaviour, are not only difficult to assess in court, but also problematic to prove to participants in the trial. As a result, positive judicial practice in this regard was absent for a long time in Russia. ${ }^{53}$ The Resolution of the Plenum of the Supreme Arbitrazh Court of the Russian Federation of 30 July 2013 No. 62 "On Certain Issues of Compensation of Losses by Persons Included in the Bodies of a Legal Entity, ${ }^{\prime \prime 4}$ in

Письмо Банка России от 10 апреля 2014 г. № 06-52/2463 «О Кодексе корпоративного управления» [Letter of the Bank of Russia No. 06-52/2463 of 10 April 2014. On the Corporate Governance Code] (Sep. 2, 2020), available at http://docs.cntd.ru/document/499090337.

49 Id.

50 Федеральный закон от 26 декабря 1995 г. № 208-Ф3 «Об акционерных обществах» [Federal Law No. 208 of 26 December 1995. On Joint-Stock Companies] (Sep. 2, 2020), available at http://www. consultant.ru/document/cons_doc_LAW_8743/.

51 Федеральный закон от 8 февраля 1998 г. № 14-Ф3 «Об обществах с ограниченной ответственностью» [Federal Law No. 14 of 8 February 1998. On Limited Liability Companies] (Sep. 2, 2020), available at http:// www.consultant.ru/document/cons_doc_LAW_17819/.

52 Florian Heindler, Corporate and Unitary Legal Entities in Russia (2018).

53 Peter B. Maggs et al., Law and Legal System of the Russian Federation (6 ${ }^{\text {th }}$ ed. 2015).

54 Постановление Пленума Высшего Арбитражного Суда Российской Федерации от 30 июля 2013 г. № 62 «О некоторых вопросах возмещения убытков лицами, входящими в состав органов 
clauses 2 and 3 clarified typical models, which eased the situation significantly. Such definitions as "dishonesty" and "unreasonable behaviour" are presumed. The Plenum emphasises that entrepreneurial activity is economically risky. The application of responsibility is impossible without the presence of a causal relationship between the actions of the governing body and the negative consequences, since their occurrence can be caused by the risky nature of entrepreneurial activity. Thus, in relation to this category of disputes, it is important to correctly assess the level of risk in the transaction (making another decision) and the measures taken by the head to analyse all the circumstances associated with the transaction (decision made). The Russian courts take as a basis various criterion borrowed from other norms of the Civil Code of the Russian Federation. For example: criteria for the innocence of a person who violated obligations, according to Article 401 of the Civil Code of the Russian Federation; criteria for apologising in accordance with the rules on fair acquisition. However, the Russian courts do not always combine them successfully. When resolving disputes, the courts, in substantiating the illegality of the manager's behaviour when concluding a transaction, are guided not by underestimating the transaction price against the market, but by the insufficiently considered decision as a whole. They don't take into account the problems that arise at the stage of its execution and result in losses, although the transaction price and didn't differ from the market. Corporate relations are part of the subject of civil law..$^{55}$ Consequently, they can be regulated in many respects by the will of their participants, for example, at the level of local acts of the organisation. Such an approach would make it easier for the judiciary to resolve disputes related to holding the head liable for losses incurred by the company in bad management decisions.

The interests of the corporate leader and the corporation don't always coincide, which is called a "conflict of interest." For example, when a manager withdraws the profile assets of the enterprise to persons under its control, which inevitably leads the company to bankruptcy. ${ }^{56}$ However, the obligation to act in good faith and reasonably prohibits the completion of transactions with personal interest. The presence of interest or its absence must be proved in court. ${ }^{57}$ In the current Russian legislation, the concept of interest is not well-formulated. ${ }^{58}$ Nevertheless, in practice, it is proposed to use the definition of the leader's interest developed by the Supreme Arbitrazh Court of the

юридического лица» [Resolution of the Plenum of the Supreme Arbitrazh Court of the Russian Federation No. 62 of 30 July 2013. On Certain Issues of Compensation of Losses by Persons Included in the Bodies of a Legal Entity] (Sep. 2, 2020), available at http://www.consultant.ru/document/cons_ doc_LAW_150888.

55 Shostak 2018.

56 Tricker 2015.

57 Hodges 2015.

58 Russian Company Law: The Essentials (Dmitry Dedov \& Alexander Molotnikov eds., 2017). 


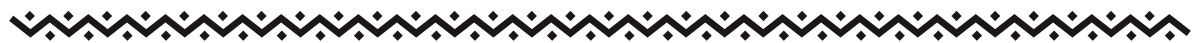

Russian Federation in the decision of 14 December 2011 No. VAS-12434/11. ${ }^{59}$ Hence, the corporate manager's interest includes any direct or indirect financial (material) interest, benefit, share, bonus, other privileges and advantages that a person can receive directly or through his/her representative, nominee holder, relative as a result of such a transaction. The powers of the corporate manager are exercised in compliance with its fiduciary duties, i.e. obligations to act on behalf of the legal entity in good faith, with due diligence, in the interests of the employer. As a preventive measure, it is necessary to consolidate the concept of interest in the charter or local corporate documents, i.e. regulations on executive bodies, regulations on the board of directors, etc. The regulation of related-party transactions allows owners to control the activities of management bodies, as well as facilitate the procedure of proof in court. Details of the assessment standards of the corporate manager's behaviour based on the interests of a particular corporation, which would be consolidated at the level of the charter or a specially developed corporate governance code of an individual organisation, can also be considered as a preventive measure. This approach to solving the problem seems optimal from the point of view of the dispositive beginning of civil law, where participants in civil area have autonomy of will while maintaining parity rights and obligations. Moreover, the provisions of the law are called upon to fulfil the role of coordinating general provisions that can be specified at the level of the agreement and local acts of the organisation.

\section{Analysis}

\subsection{Case Discussion No. 1: Anglo-Saxon Judicial Practice}

The first case for our discussion is from the Anglo-Saxon judicial practice, in which the court determines a priority or dominant goal as a criterion for the behaviour of the corporate manager of the company. Our first example involves Howard Smith Ltd., Ampol Petroleum Ltd., and RW Miller and Go, ${ }^{60}$ which was threatened by a hostile takeover by the former two companies within the same holding that

59 Определение Высшего Арбитражного Суда Российской Федерации от 14 декабря 2011 г. № BAС12434/11 по делу № А59-4783/2010. Дело об оспаривании договоров купли-продажи недвижимого имущества передано для пересмотра в порядке надзора, так как, являясь одновременно директором компании продавца и генеральным директором покупателя, лицо, действуя сдолжной осмотрительностью и добросовестностью, должно было знать об ограничении полномочий руководителя филиала на совершение сделки об отчуждении в собственность аффилированным ей лицам имущества общества [Definition of the Supreme Arbitrazh Court of the Russian Federation of 14 December 2011 No. VAS-12434/11 in case No. A59-4783/2010. The case of contesting the contracts of sale of real estate was submitted for review by way of supervision, since, being both the director of the seller's company and the general director of the buyer, the person, acting with due diligence and good faith, should have known to limit the authority of the branch manager to complete a transaction on the alienation of property of the company to its affiliates] (Sep. 2, 2020), available at http://www. consultant.ru/cons/cgi/online.cgi?req=doc\&base=ARB\&n=240589\#09666047139485675. 


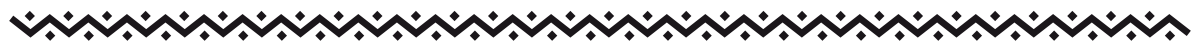

controlled a total of 55\% of the company. The director of RW Miller and Go issued a new block of shares of the company to avoid the takeover. By law, this new block of shares was required to be offered for purchase by a hostile holding. However, this was not done, and the shares were transferred to other shareholders of this company. ${ }^{61}$ The court identified two purposes for which the shares were issued when deciding whether the director was liable who decided to issue shares that were not offered for purchase by the majority shareholders. First, to increase the authorised capital, which implies that in this regard, the director acted in good faith. Second, to avoid a hostile takeover, which indicated the director's dishonesty. Since the main principle of the issue of shares was to increase the authorised capital, the critical objective out of two was conscientious; therefore, the director was not held accountable for violating the obligation, to show care, skill and diligence towards the company. ${ }^{62}$ Thus, the English court made a fair decision, determining the dominant goal in the actions of the head of the company as reasonable and conscientious.

\subsection{Case Discussion No. 2: Russian Judicial Practice}

The situation in Russian judicial practice is different. Our second example derived from the Resolution of the Arbitrazh Court of the Central District of the Russian Federation of 20 November 2017 No. F10-732/2015 in case No. A23-3760/2013. ${ }^{63}$ Berezka Ltd. agreed to supply computer equipment to LLC West to East Business Solution (USA). The total cost of the equipment amounted to 79,702.24 U.S. dollars. Equipment must have been delivered within 60 days after signing. The delivery date was the date of transfer of the equipment by the seller and written notice by the seller of the buyer about the readiness to transfer equipment according to the acceptance certificate at the place of delivery under this agreement. The buyer must have transferred the funds in the amount specified in the contract to the seller's bank

61 John Birds, Proper Purposes as a Head of Directors' Duties, 37(5) Mod. L. Rev. 580 (1974).

62 Julie Cassidy, Concise Corporations Law ( $5^{\text {th }}$ ed. 2006).

63 Постановление Арбитражного суда Центрального округа от 20 ноября 2017 г. № Ф10-732/2015 по делу № A23-3760/2013. Требование: О взыскании убытков с бывшего руководителя должника. Обстоятельства: Конкурсный управляющий ссылается на то, что бывший руководитель перечислил контрагенту по договору оказания услуг авансовый единовременный платеж при отсутствии хозяйственной необходимости для должника в получении спорных услуг. Решение: Требование частично удовлетворено, поскольку факт наличия причинно-следственной связи междудействиями руководителя должника и возникшими удолжника убытками установлен [Resolution of the Arbitrazh Court of the Central District of the Russian Federation of 20 November 2017 No. F10-732/2015 in case No. A23-3760/2013. Requirement: On recovery of losses from the former head of the debtor. Circumstances: The bankruptcy trustee refers to the fact that the former leader transferred an advance lump sum payment to the counterparty under the service agreement in the absence of economic necessity for the debtor to receive disputed services. Decision: The requirement has been partially satisfied, since the fact of the existence of a causal relationship between the actions of the head of the debtor and the losses incurred by the debtor has been established] (Sep. 2, 2020), available at http://www.consultant.ru/cons/cgi/online. cgi?req=doc\&base $=A C N \& n=107122 \# 09726527982480364$. 
account not later than the term specified in the contract. Berezka Ltd. paid to the foreign company $2,233,000$ rubles in payment of the cost of the equipment to be delivered, which corresponded to 70,000 U.S. dollars. ${ }^{64}$ However, the supplier did not fulfil its contractual obligations. Given the circumstances of the participation of a foreign partner and the number of funds payable in advance, the appellate court concluded that all of the above circumstances required the decision-maker to take special care and take into account economic security. The court of appeal also correctly indicated that it was not clear that Kobelev D.A. (as the head of the company) showed due diligence in choosing a counterparty when concluding a deal with LLC West to East Business Solution (USA). He did not take actions aimed at checking the integrity of the counterparty, its business reputation, its availability of the necessary resources for the supply of equipment that was the subject of the transaction. Hence, the Russian court, unlike the English one, was far from subjectivism, and was guided exclusively by a formally defined approach: in particular, the establishment of a causal relationship, a sign of prudence, which meant the attitude of the leader to the transaction based on external factors of economic safety of the company.

\subsection{Case Discussion No. 3: Russian Judicial Practice}

Here is another example from the judicial practice of the Arbitrazh Court of the Moscow District of the Russian Federation. The limited liability company Brokerage House "Trust Finance" applied to the Moscow City Arbitrazh Court on 21 July 2016, with a claim for the exclusion of Panin D.V. from the participants of the Upgrade Auto Plus Limited Liability Company. When checking the plaintiff's arguments, the court concluded that Panin D.V., as the general director, had committed actions that were deliberately contrary to the interests of Upgrade Auto Plus Ltd. Mr Panin made a transaction that was intentionally unfavourable for Upgrade Auto Plus Ltd. In particular, he concluded the settlement agreement in the framework of another matter without following the procedure for its approval. With his illegal actions, he appropriated the funds of Upgrade Auto Plus LLC, which were in the current account in Promsvyazbank PJSC. The court also found that at the time of signing the assignment agreement (assignment of rights) with KA Debt Collection Ltd., the debt under the loan agreement dated 28 September 2012, was already absent. As a result, the courts concluded that Mr Panin, as the general director, acted at the expense of the interests of Upgrade Auto Plus LLC when signing a settlement agreement within the framework of the case. ${ }^{65}$ This example illustrates the situation in which

64 US\$1 equals 31.9 rubles, which was an average exchange rate during 2013 according to the Central Bank of Russia.

65

Постановление Арбитражного суда Московского округа от 18 мая 2018 г. № Ф05-6322/2017 по делу № А40-156027/2016. Требование: Об исключении ответчика из состава участников общества с ограниченной ответственностью. Обстоятельства: Ответчик, являющийся участником общества с ограниченной ответственностью и одновременно являвшийся его генеральным директором, 


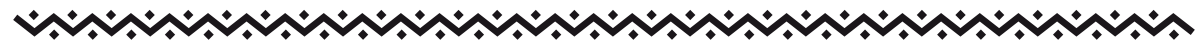

the court was guided solely by the factual circumstances of the case, referring to specific evidence. At the same time, the court did not give an assessment of the goal pursued by the head, the correlation of his personal interest and the interest of the company, the interests of other persons, including counterparties.

\section{Discussion}

The risky and competitive nature of entrepreneurial activity gives rise to a large number of managerial decision options. ${ }^{66}$ The most severe problem is the multiplicity of individuals and interest groups involved in business activity, and the consideration of their interests. The absence of clear criteria for the behavioural standards of the head of the company at the level of doctrine and legal norms creates a wide range of judicial discretion in cases of bringing the head to civil liability ${ }^{67}$ Although the Plenum of the Supreme Arbitrazh Court No. $62^{68}$ outlined the criteria for distinguishing between the concepts of entrepreneurial risk and fiduciary duties, there are still no clear limits in practice.

Quite often, in Russian legal practice, there is a confusion of the concepts of lawful and conscientious behaviour; especially, when it comes to the correlation between the categories of guilt and risk, which are directly related to the characteristics of legitimate and illegal behaviour. ${ }^{69}$ If the company manager is held liable for the damage caused to the company, we consider dishonesty as an element of a civil offence, which is unlawful behaviour. This discrepancy between theoretical and practical interpretation is also a problem area and gives a broad scope for debate. According to the provisions of paragraph 2, section 1, Article 401 of the Civil Code of the Russian Federation: guilt in civil law is considered not as a subjective attitude of a person to his//her behaviour, but as failure to take objectively possible measures to eliminate or prevent negative results of the actions dictated by specific circumstances.

совершал и совершает незаконные действия, направленные на причинение имущественного вреда обществу. Решение: Требование удовлетворено, поскольку установлено совершение ответчиком действий, заведомо противоречащих интересам общества [Resolution of the Arbitrazh Court of the Moscow District of the Russian Federation of 18 May 2018 in case No. A40-156027/2016. Requirement: On the exclusion of the defendant from the membership of a limited liability company. Circumstances: The defendant, who is a member of a limited liability company and at the same time, its general director, committed and is committing illegal actions aimed at causing property damage to the company. Decision: The claim is satisfied since it is established that the defendant has committed actions that are obviously contrary to the interests of society] (Sep. 2, 2020), available at http://www. consultant.ru/cons/cgi/online.cgi?req=doc\&base=AMS\&n=292923\#01414467509788364.

Craig S. Fleisher \& Babette E. Bensoussan, Business and Competitive Analysis: Effective Application of New and Classic Methods ( $2^{\text {nd }}$ ed. 2015).

67 Vaduva et al. 2009.

68 Resolution of the Plenum of the Supreme Arbitrazh Court of the Russian Federation No. 62, supra note 52 .

69 Russian Company Law, supra note 58. 
When making management decisions, the corporate manager conducts various civil transactions on behalf of the organisation. Initially, the head must act in the interests of the company and conclude contracts beneficial to the company. If the transaction is affiliated (if it implies his/her personal interest or his family members, as an example), he/she must receive the approval of shareholders. ${ }^{70}$ The law (i.e. Arts. 53 and 53.1 of the Civil Code of the Russian Federation) states that there is an obligation to act in good faith and reasonably but prohibits the leader from acting in personal interests and making transactions with interest. This is especially relevant in the process of declaring affiliate transactions invalid. Conflict of interests can dramatically affect the terms of transactions, which often entails loss. So, the sale of the company's property to an affiliate at a reduced price or on other preferential terms gives its owners grounds to challenge the relevant transaction in court or demand damages at the expense of the manager who committed it on behalf of the company. Russian scholars question whether actions cannot in the public interest be conscientious. ${ }^{71}$ In Russian legislation, formal criteria for presence in a conflict of interest are not formally established. Article 81 of the Federal Law "On JointStock Companies" and Article 45 of the Federal Law "On Limited Liability Companies" propose to focus on the criteria of interest in a transaction. These criteria mainly imply the presence of managerial, family or property ties. The presence of such ties cannot directly testify to the dishonesty of the leader. At the same time, paragraph 2 of the Resolution of the Plenum of the Supreme Arbitrazh Court No. $62^{72}$ states that in such a situation, dishonesty is considered to be proven.

The case of the Anglo-Saxon judicial system shows that it is not necessary to give a detailed definition of "conflict of interest" as well as precise criteria for the sake of a varied interpretation of this concept in practice. This helps to prevent dishonest directors from avoiding circumvention of the law when planning a transaction. ${ }^{73}$ When identifying transactions with a conflict of interest, we can rely on judicial precedents, since the fact of the existence of a conflict of interest confirms any aspect (most often monetary) that encourages the director to act in personal interests and with his/her own benefit at the expense of the company. For instance, in the case of Aberdeen Railway Co and Blaikie Brothers, persons with fiduciary duties should have been prohibited from entering into transactions involving the personal interest

70 Hodges 2015.

71 Бушев А.Ю. О критериях оценки решений директоров коммерческих организаций: от детальной регламентации к оценочным понятиям // Вестник Санкт-Петербургского университета. Право. 2013. № 3(14). C. 32-48 [Andrei Yu. Bushev, On the Criteria to Assess the Decisions of the Business Corporations' Director: From Detailed Regulations to Evaluative Notions, 3(14) Vestnik of Saint Petersburg University. Law 32 (2013)]; Krasnopolskaya 2020; Kulapov et al. 2019; Povarov 2017.

72 Resolution of the Plenum of the Supreme Arbitrazh Court of the Russian Federation No. 62, supra note 52 .

73 Hood 2013. 
of the designated persons that were fraught with conflict or directly contrary to the interests of the defending party. ${ }^{74}$ Company statutes supplement transaction approval rules. This incident preceded Section 177 of the Companies Act 2006 of the $\mathrm{UK}^{75}$ according to which, if directors are interested in the proposed transaction, they should merely declare this interest to the board of directors. ${ }^{76}$ Also, Section 239 states that when approving any transaction, the interested director cannot vote. ${ }^{77}$

If the company is treated as an autonomous legal entity, separate from its members and other influence groups, it is likely that the legal concept of the company coincides with the concept of influence groups. A company has the interests that are independent of any particular group of individuals associated with it, including shareholders. Thus, the role of corporate managers is to regulate the constantly changing distribution of interests. ${ }^{78}$ Also, German juridical practice does not determine the interest of the company as such but also refers to the obligation of directors to take into account the interests of shareholders, employees and other interested parties. ${ }^{79}$ As we can see, contemporary policymaking trends prompt to look at the interests of a legal entity from a different perspective. The head focuses solely on the interests of the company and takes into account the similar interests of shareholders and other parties that are directly related to the success of the company. This also includes the needs of the population and the interests of suppliers. The company, which shares various interests, is in a better position since each segment receives due attention and does not show opposition attitudes that have a detrimental effect on the overall business.

The experience of different countries, therefore, reveals the potential need to consider the complex composition of individual interests in the successful and stable development of the corporation. However, the development of the current Russian legislation regarding the normative expansion of the group of individuals whose interests the director is obliged to act is currently extremely difficult. Securing a virtually indefinite group of individuals with legally significant interests that are mandatory for the head to comply would mean blurring the limits of his/her responsibility. If the evaluation of a conflict of interest is considered as his/her duty, then its non-compliance will mean that the director commits illegal actions, which is not always the case. Therefore, the clear priority is to set for the interests of the legal

74 John Farrar \& Susan Watson, Self-Dealing, Fair Dealing and Related Party Transactions - History, Policy and Reform, 11(2) J. Corp. L. Stud. 495 (2011).

75 Id.

76 Saleem Sheikh, A Guide to the Companies Act 2006 (2013).

77 Id.

78 Michael E. Drew \& Adam N. Walk, Investment Governance for Fiduciaries (2019).

79 Christoph Torwegge, Englisches Recht. In: Treue- und Sorgfaltspflichten im englischen und deutschen Gesellschaftsrecht (2009). 
entity only. Satisfying the interests of all the others is possible insofar as they coincide with the interests of the organisation. Otherwise, such an interest will be contrary to the public one, and any actions of the leader will be regarded as unscrupulous.

As a result of this debate, we provide specific fiduciary responsibilities of the leader and the interests of a particular organisation, which would be consolidated at the level of the charter or a specially developed corporate governance code of an organisation. In order to reduce the subjective assessments in the framework of the judicial review, we propose the following behavioural model of the head of the corporation that defines the legal criteria for the good faith and reasonableness to the extent permitted by entrepreneurial risk:

- The criterion of prudence and caring borrowed from the civil law characteristics of guilt; ${ }^{80}$

-A sign of obvious evidence in the correctness of management decisions. This sign assumes the existence of economic justification, compliance with the requirements of the decision-making procedure (obtaining the information necessary for its adoption, observing the rules of inference, etc.). However, only those decisions that go beyond the scope of obvious evidence are subject to recognition as unreasonable and unscrupulous;

- Lack of personal interest of the head and decision-making taking into account the criteria of interest of the company, which are reflected in detail in its local act;

- Equal attitude to all members of the corporation in the framework of reasonable business risk;

- The intention and desire to achieve sustainable and successful development of the corporation;

- To manage the company in good faith and reasonably taking into account the "usual business conditions," to which there is a reference in clause 3 of Article 71 of the Federal Law No. 208 "On Joint-Stock Companies." ${ }^{81}$ In Russian judicial practice, it is repeatedly noted that the head of a legal entity cannot be found guilty of causing losses if he/she acted based on the usual conditions of business activities or in other words within a reasonable entrepreneurial risk;

- The absence of signs of evasion of the head without good reason from the exercise of their rights and obligations;

- A criterion of a dominant goal, which can be borrowed by Russian courts by analogy with those approaches that are reflected in Anglo-Saxon judicial precedents;

- The absence of the fact that shows the reduction the property of the corporation as a result of the actions of the head;

- The active position of the head of the corporation in court in proving his good faith and reasonable behaviour;

\footnotetext{
80 Art. 401 of the Civil Code of the Russian Federation.

81 Id. Art. 71.
} 
- The appropriate performance by the head of public law obligations assigned to him/her by applicable law.

We believe that these criteria will help the judicial authorities and practising lawyers more flexibly and objectively apply the rules of Articles 53 and 53.1 of the Civil Code of the Russian Federation, which contains the primary fiduciary duties of the head.

\section{Conclusion}

Due to frequently changing global economic systems and a sharp increase in the scale and speed of information exchange due to digitalisation and implementation of various information technologies, the use of traditional legal instruments is extremely limited. Often, legal regulations and the application of practice law are not always capable of keeping pace with the development of economic relations. ${ }^{82}$ Academic research has come to assist the process by proposing to combine ideas and experiences of foreign jurisdictions. The reception of Anglo-Saxon law has given Russian law such concepts as "corporation,"'corporate responsibility,"'managerial decisions,"'"good faith and reasonableness of a leader," and "good faith and reasonableness of a controlling person." ${ }^{183}$ Harmonisation has acquired the features of one of the leading trends in modern law. ${ }^{84}$ The convergence of legal systems is considered as a natural process..$^{85}$ In corporate legal relations, unified legal norms and uniform standards are being developed. ${ }^{86}$ However, the implementation of institutions of Anglo-Saxon law is not always suitable, and sometimes violates the traditional canons of Russian civil law. ${ }^{87}$ The task of the Russian government as the owner of legislative and judicial power is to learn how to implement and utilise new judicial tools. Thereby, it should consider changing the legal reality in the minds of participants in civil society through the adoption of relevant legal and judicial acts.

The implementation of corporate culture into the legal matter is quite innovative in Russia ${ }^{88}$. Codification of the norms of behaviour of individuals in corporate relations, development of a conventional system of values of appropriate behaviour in the interests of the company, and corporate social responsibility - these are the vital resources that form the goodwill of the company as well as are the integral parts of the brand-building process. ${ }^{89}$ The main goal of the legislation on legal entities is to ensure

\footnotetext{
82 Malecki 2018.

83 Krasnopolskaya 2020.

84 Drew \& Walk 2019.

85 Vaduva et al. 2009.

86 Tricker 2015.

87 Povarov 2017.

88 Shostak 2018.

89 Vaduva et al. 2009.
} 
a fair balance of interests between all participants in corporate relations at all stages of the life cycle of a legal entity. The norms of the good faith and reasonableness of the heads of the organisation play an important role in achieving such a balance of interests. These norms help the organisation to conduct its business activities successfully. In the presence of objective judicial discretion, as well as the absence of abuse by representatives of the business community, we believe that the positive coexistence of reasonable business risk and assessment standards in making management decisions will become an essential part of both legal and economic reality.

\section{References}

Bereskin F. et al. Whistle Blowing, Forced CEO Turnover, and Misconduct: The Role of Socially Minded Employees and Directors, 66(1) Manag. Sci. 24 (2019). https://doi. org/10.1287/mnsc.2018.3229

Birds J.R. Proper Purposes as a Head of Directors' Duties, 37(5) Mod. L. Rev. 580 (1974).

Busenitz L.W.Entrepreneurial Risk and Strategic Decision Making:It's a Matter of Perspective, 35(3) J. Appl. Behav. 325 (1999). https://doi.org/10.1177/0021886399353005

Campbell R.B., Jr. \& Frost C.W. Managers' Fiduciary Duties in Financially Distressed Corporations: Chaos in Delaware (and Elsewhere), 32(3) J. Corp. L. 491 (2007).

Cassidy J. Concise Corporations Law ( $5^{\text {th }}$ ed. 2006).

Collison D. et al. Financialization and Company Law: A Study of the UK Company Law Review, 25(1) Crit. Perspect. Account. 5 (2014). https://doi.org/10.1016/j.cpa.2012.07.006

Crotty J. Corporate Social Responsibility in the Russian Federation: A Contextualized Approach, 55(6) Bus. Soc. 825 (2014). https://doi.org/10.1177/0007650314561965

Dbe A. Regulating the Conduct of Directors, 10(1) J. Corp. L. Stud. 1 (2010). https://doi. org/10.1080/14735970.2010.11419818

De Schutter O. Corporate Social Responsibility European Style, 14(2) Eur. L.J. 203 (2008). https://doi.org/10.1111/j.1468-0386.2007.00411.x

Drew M.E. \& Walk A.N. Investment Governance for Fiduciaries (2019).

Farrar J.H. \& Watson S. Self-Dealing, Fair Dealing and Related Party Transactions History, Policy and Reform, 11(2) J. Corp. L. Stud. 495 (2011). https://doi.org/10.5235/ 147359711798110655

Filatotchev I. \& Nakajima C. Corporate Governance, Responsible Managerial Behavior, and Corporate Social Responsibility: Organizational Efficiency Versus Organizational Legitimacy?, 28(3) Acad. Manag. Perspect. 289 (2014). http://dx.doi. org/10.5465/amp.2014.0014

Fleisher C.S. \& Bensoussan B.E. Business and Competitive Analysis: Effective Application of New and Classic Methods ( $2^{\text {nd }}$ ed. 2015).

Heindler F. Corporate and Unitary Legal Entities in Russia (2018).

Ho J.K.S. "Director's Duty to Promote the Success of the Company": Should Hong Kong Implement a Similar Provision?, 10(1) J. Corp. L. Stud. 17 (2010). https://doi.org/10.1080/ 14735970.2010.11419819 
Hodges C. Law and Corporate Behaviour: Integrating Theories of Regulation, Enforcement, Compliance and Ethics (2015).

Hood P. Directors' Duties Under the Companies Act 2006: Clarity or Confusion?, 13(1) J. Corp. L. Stud. 1 (2013). https://doi.org/10.5235/14735970.13.1.1

Horn L. Corporate Governance in Crisis? The Politics of EU Corporate Governance Regulation, 18(1) Eur. L.J. 83 (2012). https://doi.org/10.1111/j.1468-0386.2011.00587.x Johnson G. et al. Exploring Strategy (2014).

Langford R.T. The Duty of Directors to Act Bona Fide in the Interests of the Company: A Positive Fiduciary Duty? Australia and the UK Compared, 11(1) J. Corp. L. Stud. 215 (2011). https://doi.org/10.5235/147359711795344181

Maggs P.B. et al. Law and Legal System of the Russian Federation ( $6^{\text {th }}$ ed. 2015).

Malecki C. Corporate Social Responsibility: Perspectives for Sustainable Corporate Governance (2018).

Marnet O. Behavior and Rationality in Corporate Governance, 39(3) J. Econ. Issues 613 (2015). https://doi.org/10.1080/00213624.2005.11506837

Mintzberg H. Strategy-Making in Three Modes, 16(2) Calif. Manag. Rev. 44 (1973). https://doi.org/10.2307/41164491

Nosworthy B. A Director's Fiduciary Duty of Disclosure: The Case(s) Against, 39(4) U.N.S.W.L.J. 1389 (2016).

Orlov V. Introduction to Business Law in Russia (2013).

Ribstein L.E. Are Partners Fiduciaries?, 2005(1) U. Ill. L. Rev. 209 (2005).

Sheikh S. A Guide to the Companies Act 2006 (2013).

Shostak S.A. Russia Corporate, Financial, and Commercial Law (2018).

Torwegge C. Englisches Recht. In: Treue- und Sorgfaltspflichten im englischen und deutschen Gesellschaftsrecht (2009). https://doi.org/10.1007/978-3-8349-8204-9_2

Tricker B. Corporate Governance: Principles, Policies, and Practices (2015).

Van Greuning H. \& Brajovic-Bratanovic S. Analyzing Banking Risk: A Framework for Assessing Corporate Governance and Risk Management ( $3^{\text {rd }}$ ed. 2009).

\section{Information about the authors}

Sergey Sosnovskikh (Leicester, United Kingdom) - Lecturer in Business and Management, De Montfort University (The Gateway, Leicester, LE1 9BH, United Kingdom; e-mail: sergey.sosnovskikh@dmu.ac.uk).

Oxana Cherkasova (Yekaterinburg, Russia) - Senior Lecturer in Civil Law, Ural Federal University (51 Lenin Av., Yekaterinburg, 620075, Russia; e-mail: o.v.cherkasova@urfu.ru). 